\title{
Occurrence of invasive alien plant species in the floodplain forests along the Mura River in Slovenia
}

\author{
ALEKSANDER MARINŠEK ${ }^{1}$ \\ LADO KUTNAR ${ }^{1}$ \\ ${ }^{1}$ Slovenian Forestry Institute, Večna pot 2, \\ SI-1000 Ljubljana \\ Correspondence: \\ Aleksander Marinšek \\ E-mail: aleksander.marinsek@gozdis.si

\section{Nonstandard abbreviations} \\ FHT - forest habitat type \\ IAS - invasive alien species
}

Key words: non-native plants; riparian vegetation; habitat type; habitat loss; canopy closure; forest management; conservation management
Received January 30, 2017.

Revised October 09, 2017.

Accepted December 27, 2017.

\begin{abstract}
Background and purpose: The objectives of our study were to identify invasive alien plant species (IAS) in the main Natura 2000 forest habitat types (FHT) along the Mura River in Slovenia, and to estimate their abundance and cover. The aim of our study was to find out a) Which IAS appear in the research forests? b) What is their frequency and cover percentage? $c$ ) Whether individual IAS prosper better in some FHT than others? d) What is the correlation between the cover of IAS and the tree layer cover?
\end{abstract}

Materials and methods: We analysed the fidelity of invasive plant species to individual FHT. The studied FHTs along the Mura River were the following: 91EO* (Alluvial forests with Alnus glutinosa and Fraxinus excelsior), 91F0 (Riparian mixed forests of Quercus robur, Ulmus laevis and Ulmus minor, Fraxinus excelsior or Fraxinus angustifolia, along the great rivers) and $91 L 0$ (Illyrian oak-hornbeam forests). Two forest areas of about $600 \mathrm{ha}$ were studied in total. With the intention to calculate number and cover of IAS some statistical analysis was made. In addition, correlations between the abundances of the most present IAS and cover of upper tree layer were carried out.

Results: In total, 15 IAS were recorded in studied FHTs. Some species, like Robinia pseudoacacia, Impatiens glandulifera, I. parviflora, Fallopia japonica (incl. F. x bohemica), Erigeron annuus, Ambrosia artemisiifolia, Amorpha fruticosa, Conyza canadensis and Juncus tenuis occur only in one or two FHTs, while some species can be found in all studied FHTs (e.g. Solidago $s p$.). We found out that the most threatened forests are those with prevailing Salix alba, Alnus glutinosa, Fraxinus angustifolia and Ulmus laevis tree species. Those are the forests of FHT 91EO which have less dense tree canopies, grow closest to the river and on the wettest sites. We found a statistically significant higher number and cover of IAS in the FHT 91EO and the lowest number and cover in FHT 91LO.

Conclusions: Alluvial forests with Alnus glutinosa and Fraxinus excelsior (FHT 91EO) along the Mura River are most prone to invasion of IAS. The increasing presence of IAS in the study areas seriously affects natural regeneration, stability, and continuity of floodplain forests in all other FHTs in the study area. At the same time the amount of IAS in these forests also depends on management measures and their intensities which accelerate light availability. Some measures and guidelines for managing of these forests with the purpose of reducing IAS impacts are suggested in this study.

\section{INTRODUCTION}

Tnvasive alien species (IAS) are introduced plants (non-native) that have been transported outside their natural ecological range because of human actions and can spread and invade new habitats. IAS can 
survive, reproduce and rapidly spread without human help. The term 'invasive' is most often utilized for any introduced species ('nonindigenous' or 'non-native') that can degrade the habitats they invade (1). The arrival of IAS can disrupt an ecosystem equilibrium, alter its nature, and affect the provision of services, such as altering water or soil quality, or interfering with pollination (2). IAS are viewed as a disturbance with negative impact on native species and ecosystems (3). Biological diversity, or more appropriately species richness, can be affected in various ways. IAS can pose a major threat to native species and habitats through competition and transmission of diseases. They can reshape the functioning of entire ecosystems. For example, black cherry (Prunus serotina) is out shading the ground vegetation and preventing rejuvenation of native forest trees; it effects forest succession (2) and is recognised as an alien species which is rapidly invading European forests $(4,5,6)$. Such species are not a novelty in our ecosystems and are identified as a growing threat to Europe's native flora, fauna, habitats, and economy $(2,7)$. They are also considered as one of the most important causes of diversity loss (after habitat loss and fragmentation) (2). It is estimated that there are already over 12,000 alien species (not only plants!) present in Europe, of which around $10-15 \%$ are invasive. They are represented by all major taxonomic groups, ranging from mammals, amphibians, reptiles, fish, invertebrates and plants to fungi, bacteria, and other micro-organisms. They are also found in every type of habitat, both on land and in the surrounding seas (8).

The occurrence of floodplain forests in Central Europe is usually related to natural conditions with specific soil moisture regimes. Such areas are under strong influence of hydrology of through-flowing streams and rivers and have been gradually formed by rivers and their flood sediments (9). Also, the parent rock (usually gravel deposits of varying thickness) and soils (diversity of alluvial sediments) create special ecological site conditions. The importance of floodplain forests varied throughout the history, but nowadays their importance lies in high timber production, high biodiversity of flora and fauna, they serve as nature reserves, as a water retention device in case of flooding and have aesthetic landscape functions and are of recreational use (10). At the same time, these forests and their functions are disturbed and degraded by human activities, which include reducing the floodplain forest area, channelizing and shortening of watercourses, constructing hydropower plants and retention reservoirs, fragmenting ecosystems, extracting gravel and sand deposits and high game stock levels $(10,11)$.

Floodplain forests are extremely prone to invading of IAS because those species spread easily in the frequently disturbed areas created by flooding and tend to thrive in rich soils of floodplain forests. Rivers function as vectors for transferring IAS propagules and at the same time occasional floods also help to spread IAS, as they transfer seeds and other plant propagules into nearby terrestrial ecosystems and vice versa; from terrestrial ecosystems into a riparian zone and rivers (12). Currently, in the terms of IAS the most threatened areas in Slovenia are flooded zones of lowland rivers: the Sava downstream, the Ljubljanica, the Krka, the Drava and the Mura. Zelnik (13) found out that the highest number of data about the presence of IAS in Slovenia referred to riparian zones (44\%). The second highly infected group of habitats are floodplain woods.

Floodplain forests along the Mura River in the northeastern part of Slovenia belong to unique forest ecosystems $(14,15)$, and represent an important part of European natural heritage, which deserve great attention in terms of the scientific analysis of their history, condition, protection, conservation, and revitalization $(2,53)$. These forests are among the most extensive $(16,17,18)$ and the most preserved floodplain forests in Slovenia (19). Their existence is very important for the conservation of endangered and protected animal and plant species, e.g. Ciconia nigra, Cucujus cinnaberinus, Castor fiber, Lutra lutra, Triturus dobrogicus, Fritillaria meleagris, Leucojum vernum, Iris sp., Trapa natans, and their habitats. Unfortunately, their structure, species composition and dynamics are increasingly endangered by IAS, which represent one of the most serious threats to such ecosystems, causing species richness decline, lower aesthetic value and hinder natural rejuvenation of indigenous tree species.

According to the Ellenberg et al. (20) most of the invasive alien plants prefer nutrient-rich and sunny sites (13), which are frequently found in floodplain forests. Although some researches of flora (e.g. 11, 21) and IAS in various habitats in the area is made $(13,15,22,23)$, indepth researches of IAS presence and their impacts on native plant communities and Natura 2000 forest habitats along the Mura River are scarce.

The main goal of our study was to find out answers to the following questions: a) Which IAS appear in the in the Natura 2000 forest habitat types (FHT) along the Mura River in Slovenia? b) What is their frequency and coverage) Do individual IAS prosper better in some FHT than others? d) Is there any correlation between the coverage of IAS and tree layer?

\section{MATERIAL AND METHODS}

The research area is located near the Mura River in the north-eastern part of Slovenia, in its sub-Pannonian region. The Mura is a river in Central Europe rising in the Hohe Tauern national park of the Central Eastern Alps in Austria, with its source being at $1898 \mathrm{~m}$ above sea level and further runs through Slovenia and Croatia. Its total length is around 480 kilometres. About $330 \mathrm{~km}$ is within the border of Austria, $95 \mathrm{~km}$ flow in and around Slovenia (67 km along the borders with Austria and Croatia, 28 


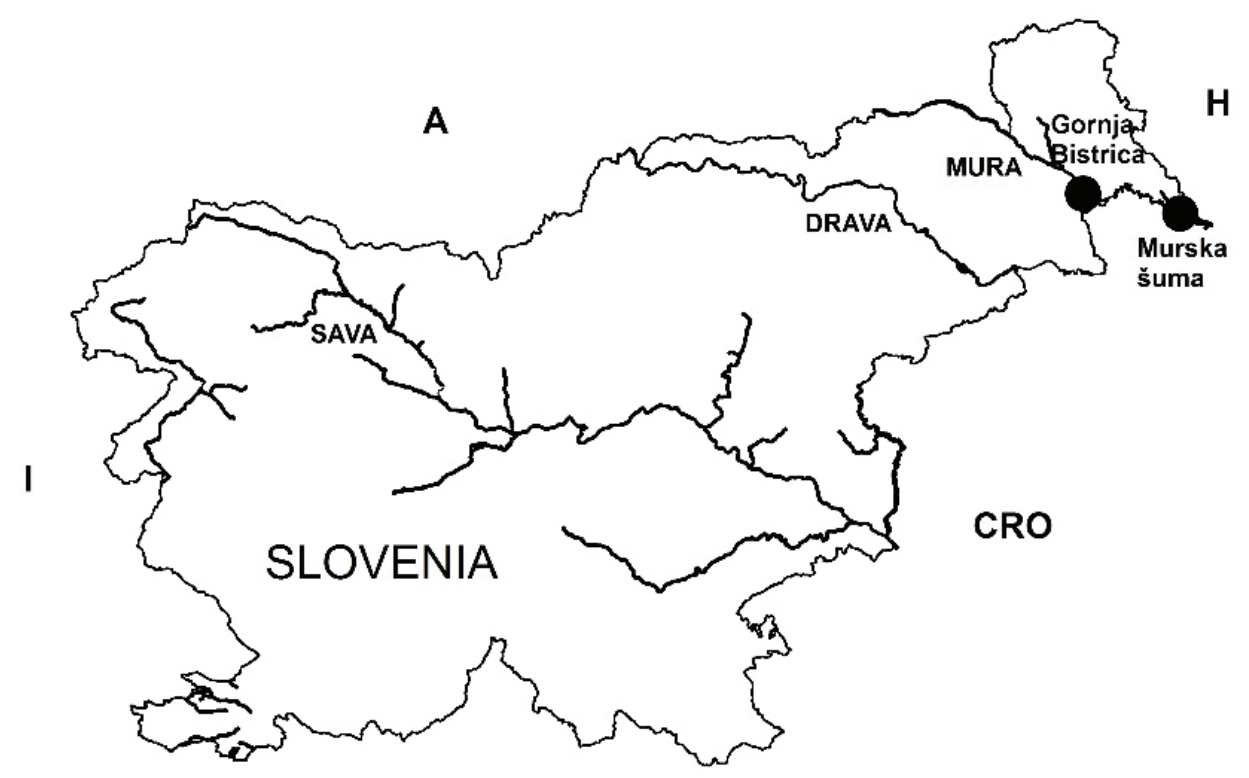

Figure 1. Position of the Mura River in Slovenia and two locations of our research areas Gornja Bistrica and Murska šuma.

$\mathrm{km}$ inside Slovenia) and the rest forms the border between Croatia and Hungary (24). The upper stream of the river has the character of an alpine river, but in the lowland (partly in Austria, mostly in Slovenia and Croatia) it becomes a typical Pannonian lowland river, meandering back and forth across plains, gradually changing its course over the centuries. With occasional flooding it affects human life, dynamics, and ecology of forests nearby. The area has a continental climate with the annual mean temperature of $9.2^{\circ} \mathrm{C}$ and the annual mean precipitation of $800 \mathrm{~mm}$. Since the area is composed mainly of sandstone, the flora shows a mainly central European floristic character (14).

For the purpose of this study, we selected two forest complexes along the Mura River: Gornja Bistrica and Murska šuma (Figure 1) with the total area of 600 hectares. Each of those two complexes are almost the same size, they have comparable site conditions, but different ownership. Forests in Gornja Bistrica are mainly private owned and the forests in Murska šuma are in general state-owned. We were focused on three FHTs in this area, and according to a classification in Annex 1 of Habitat directives $(25,26)$ are following: $91 \mathrm{E} 0^{*}-$ Alluvial forests with Alnus glutinosa and Fraxinus excelsior (Alno-Padion, Alnion incanae, Salicion albae), 91F0 - Riparian mixed forests of Quercus robur, Ulmus laevis and Ulmus minor, Fraxinus excelsior or Fraxinus angustifolia along the great rivers (Ulmenion minoris), 91L0 - Illyrian oak-hornbeam forests (Erythronio-Carpinion).The two forest habitat types, 91E0 and 91F0, are present in both complexes, while FHT 91L0 is presented mainly in Murska šuma. Comparison of this FHT between locations have not been carried out for this reason.
Vegetation of floodplain forests was investigated according to the standard Central European method (27) in the summer of 2015. We elaborated 130 relevés of floodplain forests using a network placed on the map of habitat types, which were mapped in 2013 on the scale of 1:3.500. The plot size was $200 \mathrm{~m}^{2}$. We assessed coverage of individual vertical vegetation layers (upper tree, lower tree, shrub, and herb layer) and an assessment of IAS coverage in each of these layers. For the cover estimation, the Braun-Blanquet (27) scale was used, and the cover was visually estimated. Differences between number and cover of IAS and forest habitat types and locations were tested by Kruskall-Wallis test using Statistica software (28). Also, a Spearman rank order correlation between IAS coverage and cover of upper tree layer was calculated using Statistica software (28).

Species' name Solidago sp. was used as a common name for species Solidago gigantea and Solidago canadensis. Because of the fast recognition difficulties (29), we did not distinguish them during the field work. We did the same for the taxa Fallopia and Parthenocissus. The name Fallopia sp. in this article is used for both species thriving in this area: F. japonica and F. $x$ bohemica, while the name Parthenocissus sp. is used for $P$. quinquefolia and $P$. inserta.

\section{RESULTS}

The study revealed high presence of IAS in the studied forests. In Table 1 fifteen IAS, which were found in the study area, are listed.

The most frequently occurring IAS was Impatiens glandulifera, which was recorded in $51 \%$ of plots. Other more frequent species were the following: Acer negundo (38\%) 
Table 1. List of invasive alien species and their frequency recorded in the research plots in Gornja Bistrica and Murska šuma in 2015.

\begin{tabular}{|lcc|}
\hline IAS & $\begin{array}{c}\text { Presence on plots } \\
\text { (out of 130) }\end{array}$ & \% of plots \\
\hline Impatiens glandulifera & 67 & 51.0 \\
Acer negundo & 49 & 38.0 \\
Solidago sp. & 37 & 28.0 \\
Robinia pseudoacacia & 14 & 11.0 \\
Duchesnea indica & 13 & 10.0 \\
Impatiens parviflora & 5 & 4.0 \\
Echinocystis lobata & 4 & 3.0 \\
Erigeron annuus & 4 & 3.0 \\
Fallopia sp. & 4 & 3.0 \\
Parthenocissus sp. & 3 & 2.0 \\
Ambrosia artemisiffolia & 1 & 0.7 \\
Amorpha fruticosa & 1 & 0.7 \\
Conyza canadensis & 1 & 0.7 \\
Juncus tenuis & 1 & 0.7 \\
Rudbeckia laciniata & 1 & 0.7 \\
\hline
\end{tabular}

in the herb, shrub and tree layers, Solidago sp. (28\%) in the herb layer, Robinia pseudoacacia (11\%) in the herb, shrub and tree layers, and Duchesnea indica (10\%) in the herb layer. Fallopia sp. was found in only 4 plots, mainly under less dense forest canopies. The same pattern was established for Impatiens parviflora, Echinocystis lobata, Parthenocissus sp. and Erigeron annuus (Table 1). Species like Ambrosia artemisiifolia, Rudbeckia laciniata, Conyza canadensis, Juncus tenuis and Amorpha fruticosa were very rare and found only sporadic. Those are not typical forest species and were mainly found on paths, skid rows, forest edges and small gaps inside a forest matrix, where light availability is higher due to sparse tree canopies.

Beside this we also found two alien, however (so far) non-invasive, species thriving in this sites: Juglans nigra and Fraxinus americana. The first one was found in 14\% and the second one in $11 \%$ of the research plots. Both species were planted in the past and are now rejuvenating, mainly in the forests of 91F0 and 91L0 habitat types.

The IAS coverage in FHT 91E0 is significantly higher than in FHT 91F0 and 91L0 (p < 0.001) (Figure 2a). We found out that the mean coverage of IAS in the FHT $91 \mathrm{E} 0$ was around $9 \%$, while the mean cover of IAS in other two FHTs is between 1 and 3\% (Figure 2a). The

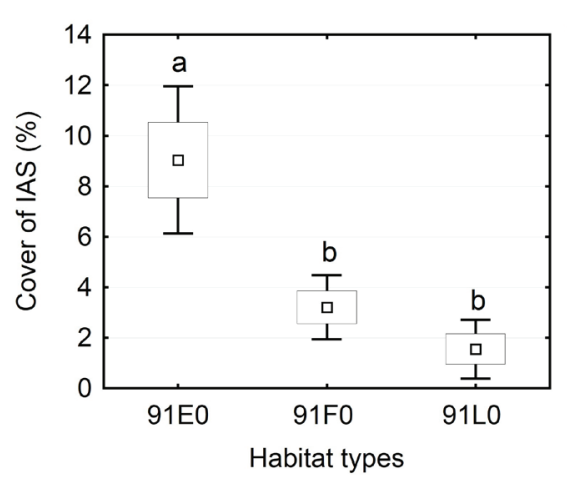

a)

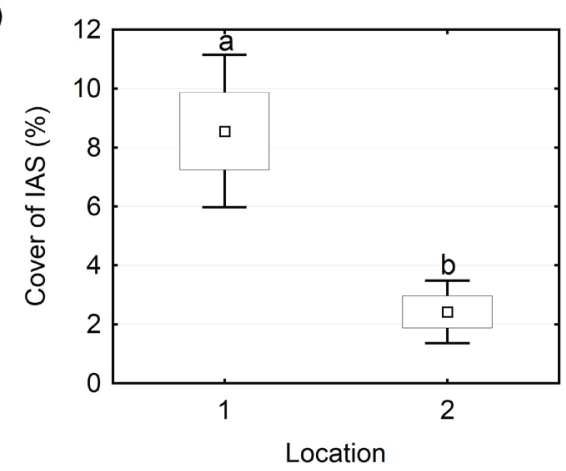

b)

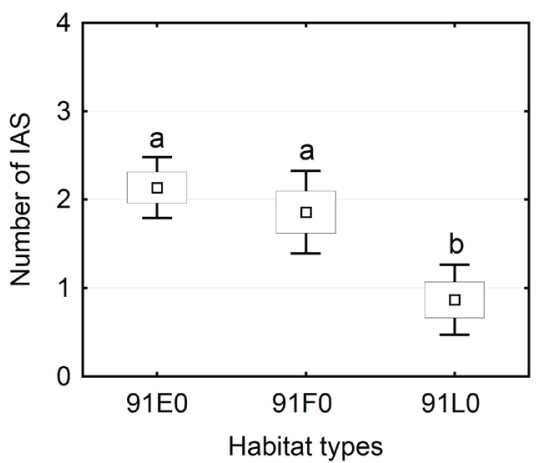

c)

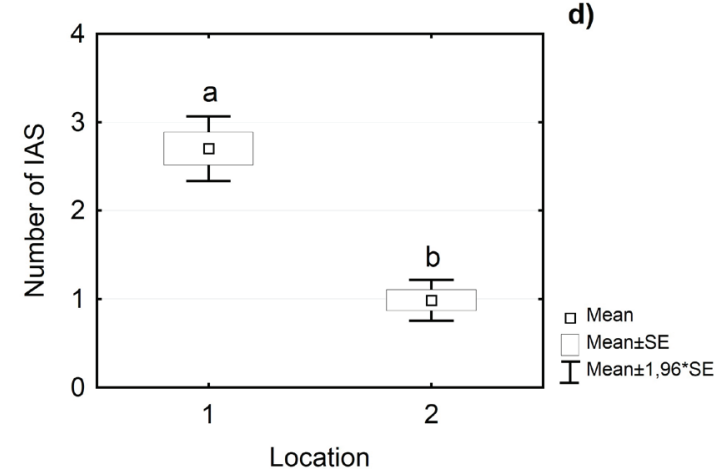

Figure 2. Percentage cover of IAS according to the individual FHT (a), number of IAS according to the individual FHT (b), percentage cover of IAS according to the location (c), and number of IAS according to the location (d). $(1=$ Gornja Bistrica, $2=$ Murska šuma, 91EO - Alluvial forests with Alnus glutinosa and Fraxinus excelsior, 91FO - Riparian mixed forests of Quercus robur, Ulmus laevis and Ulmus minor, Fraxinus excelsior or Fraxinus angustifolia along the great rivers, 91LO - Illyrian oak-hornbeam forests), $a$ and $b=$ groups with the same letter are not significantly different from each other at $p<0.001$. 


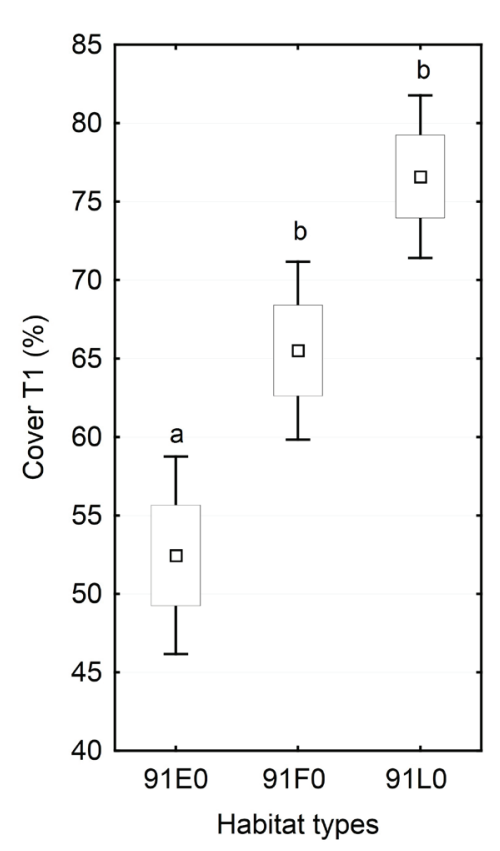

a)

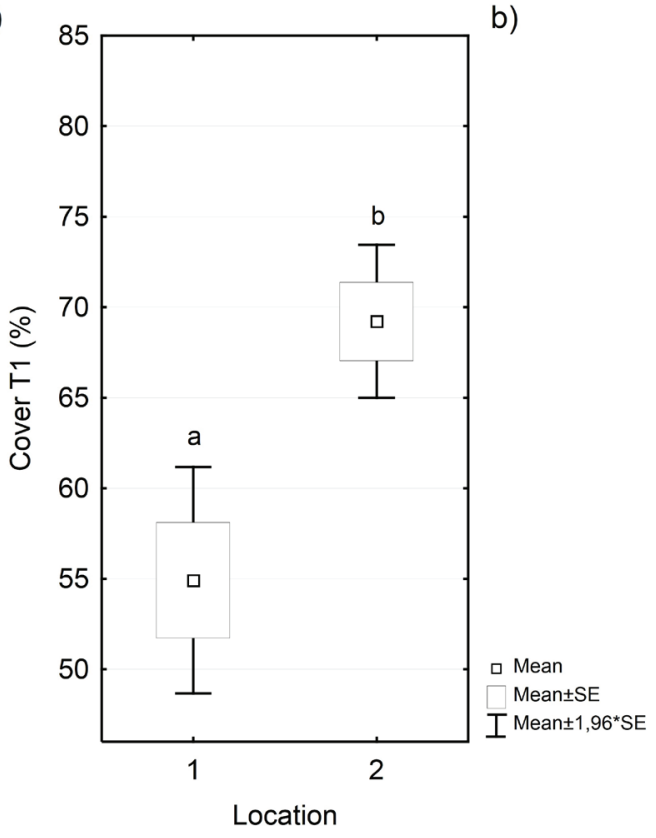

Figure 3. Cover of upper tree layer (T1) significantly varies according to FHT (a) and according to location (b) $(1=$ Gornja Bistrica, $2=$ Murska šma). $a$ and $b=$ groups with the same letter are not significantly different from each other at $p<0.001$.

highest number of IAS was found in the FHT 91E0 $\left(\mathrm{N}_{\text {mean }}=2.2\right.$ spec./plot $)$ which was significantly higher than in FHT 91L0 $\left(\mathrm{N}_{\text {mean }}=0.9\right.$ spec./plot $)(\mathrm{p}<0.001)$. The difference in number of IAS was also significantly different between FHT 91F0 ( $\mathrm{N}_{\text {mean }}=1.9$ spec./plot $)$ and 91L0 ( $p=0.01068$ ), while no difference was detected between FHT 91E0 and 91F0 (Figure 2b). Regarding differences between the two study areas, it showed that the cover of IAS was significantly higher in the forest stands in Gornja Bistrica $(\mathrm{p}<0.001)$ (Figure 2c). Mean coverage of IAS per plot in Gornja Bistrica was around 9\%, while in Murska šuma it was around 3\% (Figure 2c). Furthermore, the number of IAS was significantly higher in Gornja Bistrica $\left(\mathrm{N}_{\text {mean }}=2.7\right.$ spec./plot $)$ than in Murska šuma $\left(\mathrm{N}_{\text {mean }}=1.0\right.$ spec./plot $)(\mathrm{p}<0.001)$ (Figure $2 \mathrm{~d}$ ).

The cover of upper tree layer in FHT 91E0 is significantly lower than in 91F0 ( $=0.015)$ and in 91L0 ( $<<$ 0.001 ), while there is no significant difference between 91F0 and 91L0 (Figure 3a). Coverage of upper tree layer (T1) in Gornja Bistrica, regardless of FHT, was found significantly lower than the one in Murska šuma ( $\mathrm{p}<$ 0.001) (Figure 3b). Consequently, lower values of upper tree layer coverage mean more open stands with higher availability of light favouring the IAS growth.

It turned out that individual IAS are not equally represented in our three observed FHTs. Focusing on the only four of the most frequently recorded species (Table 1), we can see in the Figure 4, that Acer negundo in the lower tree and the shrub layer is not presented in FHT 91L0 and the same goes for the characteristic of Robinia pseudoacacia in upper and lower tree layers. Acer negundo is more tied to 91E0 FHT, where in some cases it covers more than $30 \%$ and up to $50 \%$ of the surface. Robinia pseudoacacia prefers drier ecological conditions and therefore it is better thriving in the forests of FHT 91F0, especially in the upper tree layer. Its mean coverage in the study plots is near $3 \%$, but in some cases its coverage rises to $40 \%$, although maximum values are not shown in Figure 4. Under the canopy of other tree species, in lower tree layer (T2), Robinia pseudoacacia is not a successful competitor and its frequency and covering in lower vertical layers are considerably decreased. The most frequent IAS and at the same time IAS which occupies mainly the wettest sites (FHT 91E0 and 91F0) is Impatiens glandulifera. In the alluvial forests of Salix alba and Alnus glutinosa (91E0), the mean coverage of Impatiens glandulifera is about $11 \%$ on average (Figure 4), while in some cases exceeds $30 \%$ and goes up to $80 \%$ where they suppress all other plants and build impassable or very dense stands. At the same time, the species is very rare in the driest sites in Illyrian oak-hornbeam forests (91L0). Regarding its occurrence in different FHTs, it is the only IAS, which has significantly higher cover in the forests of 91E0 in relation to the other two FHTs (Figure 4) (p < $0.001)$. The only IAS that was recorded in our research area and occurred in all FHTs almost evenly, is Solidago sp., found in $28 \%$ of the relevés (Table 1).

Most of the IAS are high light-requiring species and therefore dense canopy closure reduces their occurrence and coverage in the forest stands. It demonstrated that 

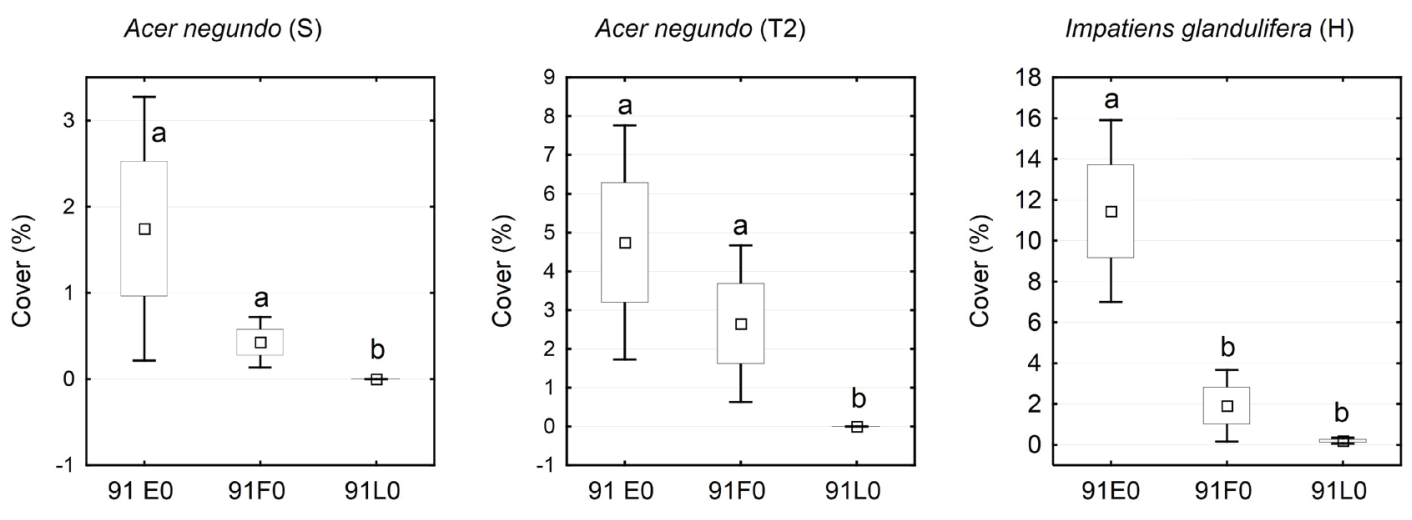

Robinia pseudacacia (T1)

Robinia pseudacacia (T2)
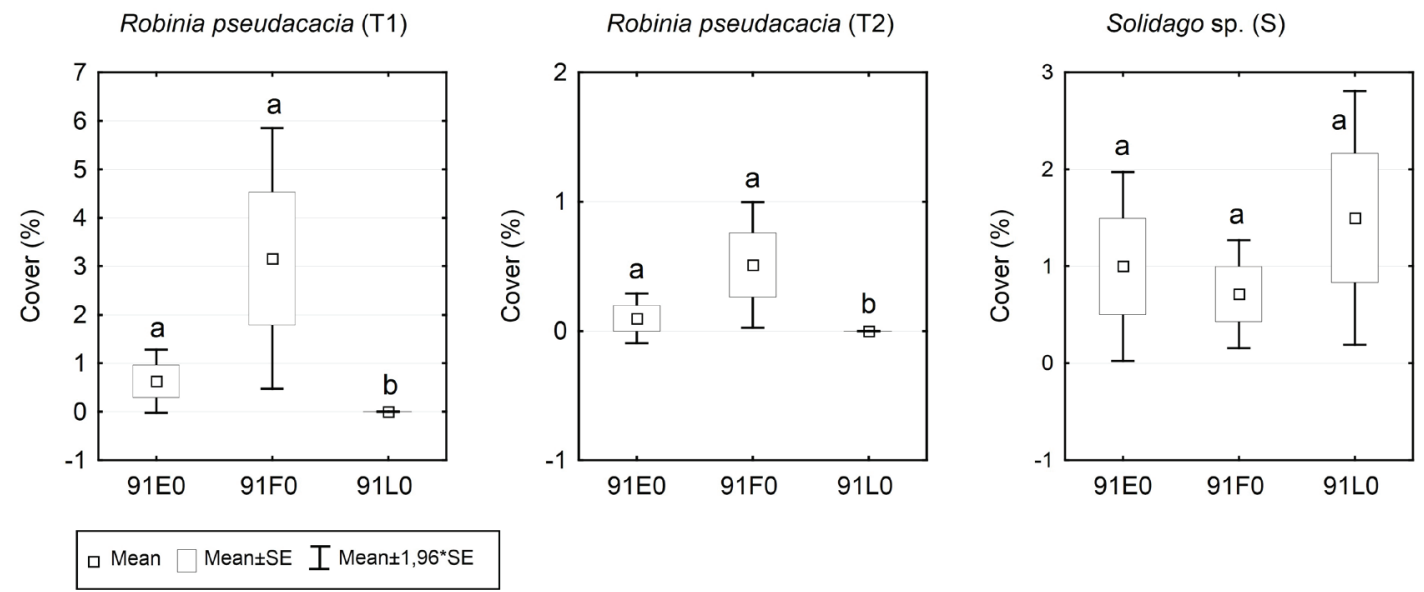

Figure 4. The most frequent IAS in the research area presented according to forest habitat type (91EO - Alluvial forests with Alnus glutinosa and Fraxinus excelsior, $91 F 0$ - Riparian mixed forests of Quercus robur, Ulmus laevis and Ulmus minor, Fraxinus excelsior or Fraxinus angustifolia along the great rivers, $91 L 0$ - Illyrian oak-hornbeam forests) and vertical vegetation layers $(T 1=$ upper tree layer, T2 = lower tree layer, $S=$ shrub layer, $H$ = herb layer $)$.

declining trend was indicated for most of the frequent IAS of the area, but statistical significant negative trend was proven only for Impatiens glandulifera (corr. $=-0.438, \mathrm{p}<$ 0.001). Therefore, according to Figure 3 and 4, we claim that the forests of FHT 91E0 in Gornja Bistrica are most prone for the invasion of Impatiens glandulifera and other IAS. At the same time, dense canopy cover of forests of FHT 91L0 in Murska šuma, offer least favourable light conditions for its thriving.

\section{DISCUSSION}

Our research showed that riparian and flooded forests are among the most threatened habitats by IAS. We registered 15 taxa (on species and genus level) out of 32 species, which are classified as IAS in Slovenia (30). According to Jogan et al. (30) the list of 32 plants could easily be expanded with another 71 species that have been already naturalized. Nevertheless, all the taxa with the most negative influence on the species richness in forest habitats in Slovenia, which are found by Zelnik (13), were record- ed in the research area in the forests along the Mura River, which Zelnik (13) did not include in his study. Those species are: Robinia pseudoacacia, Solidago gigantea, Juncus tenuis, Rudbeckia laciniata, Erigeron annuus, Impatiens glandulifera and Impatiens parviflora. With our study, we get insight into the distribution and thriving of individual IAS among three different FHTs, which differ from one another on the base of ecological conditions and in the distance from the water and frequency of floods. Water and occasional floods are a very important factor and vector for dispersing IAS (17). Zelnik et al. (31) found out that the number and abundance of IAS in a riparian zone were strongly positively correlated with the distance from a river source, while they were negatively correlated with altitude, vegetation structure complexity, completeness of riparian zone and current velocity.

During the study, we have assumed and later also confirmed the difference among FHTs in terms of IAS frequency and coverage. This is in line with findings of Hejda et al. (32) who claim that the type of the invaded community is another factor that can explain differences 
in the impact exerted by individual species of invasive neophytes. In our case the differences between the FHTs are due to different ecological conditions; in terms of their flooding dynamics, altitude, and thus the amount of groundwater and soil water content. Differences are also due to light conditions, as canopy closure directly influences the amount of direct sunlight which penetrates to the forest ground. FHTs differ also in soil characteristics, water level, distance from water bodies and stand characteristics. For example, stands in the FHT 91E0* (Alluvial forests with Alnus glutinosa and Fraxinus excelsior) are usually closest to water bodies and at the same time not very dense. In this case, it turned out that these forests are the most burdened with IAS regarding their number and cover (Figure 2).

We found forests of FHT 91L0 (Illyrian oak-hornbeam forests) to be the least prone to the IAS invasion. We assume that the reasons for a lower abundance and lower number of IAS are drier site conditions, longer distance from water bodies, low frequency of floods, and stand structure with dense crown canopies and lower light intensity, which is a result of forest management. In the forests of this FHT we have not recorded two of the most frequent IAS trees - Robinia pseudoacacia and Acer negundo. Rudolf and Brus (23) found Robinia pseudoacacia in comparable sites with the oak-hornbeam stands to be more frequent, but locations of their study plots where either distant from the Mura River or were placed at the upper part of the river region, which is known as relatively less preserved in terms of forest management and stand structure. Rudolf and Brus (23) also conclude that rejuvenation of Robinia pseudoacacia was infrequent in this area and suggest that it will not increase largely in the future. Absence of Acer negundo in this FHT is expected because this species prefers bright sunlight conditions and grows on flood plains and other disturbed areas with ample water supply, such as riparian habitats. On the other hand, the species is very successful in FHT 91E0, where in some places composes clear stands with Solidago sp.

We expected much higher occurrence of Fallopia taxa, but it proved that the species is very rare in all the FHTs of regular and occasional flooded forests along the Mura River in our research area. It was recorded in only 4 relevés out of 130 (Table 1). Our results are in accordance with the results of Tiébré et al. (33) and Zelnik et al. (31), as they claim that habitat destruction, fragmentation and short-term disturbance play very important roles in the distribution of $F$. japonica and they found it in abundance in the places where anthropogenic disturbances are frequent. We detected this species in some cases to be abundant, but mainly outside forest.

It seems that the forests along the Mura River are constantly changing, due to IAS and other reasons, such as changing ecological conditions (modified regime of flooding, lowering of ground water level etc.). In this respect, it is not only local plant species diversity $(34,35)$ and species richness affected, but this could also significantly reduce fitness and growth of resident plant species and change plant community structure by decreasing species abundance and diversity (36). IAS could increase ecosystem productivity and alter the rate of nutrient cycling (37, 38) and impact upon ecosystem services and human wellbeing (39). Regarding ecosystem impacts this would mean IAS enhanced soil microbial activity, available N, $\mathrm{P}$ and $\mathrm{C}$ pools, and decreased $\mathrm{pH}$ (36). Impacts of IAS on plant species and communities are substantial, whereas those on nutrient cycling are relatively minor (36). However, it should be noted that the current understanding of invasive plant impacts is restricted to relatively few dominant alien species (40).

The most acute problem in the studied FHTs, from forestry and conservation point of view, is rejuvenation of key tree species. Particularly, there is an ongoing problem in the case of Salix alba, Populus nigra and Alnus glutinosa forests, where dieback of Fraxinus angustifolia is caused by Chalara fraxinea and dieback of Alnus glutinosa caused by Phytophtora alni (15). At the same time, current forest management of oak (Quercus robur) does not promote its natural rejuvenation. On top of all the problems, there is also an intrusion of tall and abundant IAS which inhibit and prevent natural rejuvenation. Our research revealed that especially in the FHT 91E0 and 91F0 some IAS prevail over native plants, especially in the forest gaps, where light conditions improved. For example, Acer negundo and Imapatiens glandulifera, literally overgrew other plants, including young tree species in the herb layer. Impatiens glandulifera, which is the most abundant IAS in the researched forests, especially in FHT 91E0, grows in tall, dense stands. IAS usually affect resident communities only if they are dominant $(41,42,43)$, but regarding Impatiens glandulifera, Hejda \& Pyšek (44) found out that its effect on the species diversity of invaded communities is very weak, unlike Heracleum mantegazzianum or Fallopia japonica. These two species are the most prominent species building large stands with high cover and they further exhibit affinity to riparian habitats $(45,46)$. So far, the forests along the Mura River are not very threatened by Fallopia japonica. Even less due to Heracleum mantegazzianum, which is not present in this area. In some communities, Impatiens glandulifera can hardly eliminate native clonal dominants such as Urtica dioica, but under certain conditions it is reported to be a better competitor (47), as it turned out in our case. But the research of Hejda and Pyšek (44) reveals that invasion of Impatiens glandulifera did not alter the species composition in terms of the presence and absence of species; only proportional covers, especially those of dominant species have slightly changed. On the other hand, Ruckli et al. (48) found out that Impatiens glandulifera in mixed deciduous forests negatively affects the symbiotic association between fungi arbuscular mycorrhiza and Acer pseudoplatanus saplings and thus forest regeneration. 
Solidago sp. proved as a plant which is not thriving in only one FHT, but it is in our case represented in all FHTs almost equally (Figure 4). At the comparable sites Škornik et al. (11) found that Solidago gigantea expanded very rapidly after abandonment of wooded meadows. They found a clear positive correlation between cover-abundance values of $S$. gigantea and light intensity, but with the establishment of a shrub layer, their cover-abundance declines, however it does not disappear. The species proved it can also thrive in the conditions with lower light intensities (Figure 4) and the arrival of such species in the forest stands should worry us the most. Another problem that becomes apparent as the pool of invaders grows and the size of native habitats decreases, is the proportionally greater influx of alien plant seeds into smaller patches of native vegetation (e.g. 49). A "seed swamping" effect could increase the net establishment of invaders, even if they are unable to develop self-sustaining populations within native habitats (50).

Various authors $(51,52)$ claim that the places from which an invader was removed can become especially prone to invasion by other alien species because of available space and often disturbed ecosystem characteristics. Impatiens glandulifera in the Czech Republic is subjected to occasional eradication efforts (43), but the long-term effects of these rather unsystematic schemes are very limited because the populations usually re-invade within few years (5). At the same time, some native species can effectively reduce the cover of Impatiens glandulifera, e.g., the climber Galium aparine by proliferation of its fragile stems (54). Additionally, destroying riparian stands of Impatiens glandulifera can open the habitat for more aggressive invasive plants such as Fallopia japonica (44). Our opinion is that we should focus our strengths on IAS that are not yet present in our forests, or their number is low, and presence only local. In our case, it is meaningful to pay attention and maybe conditionally eradicate the following IAS: Amorpha fruticosa and Juncus tennuis. In our study, they were both found in only one location, therefore eradication and monitoring would make sense. Otherwise, taxa Juncus tennuis is relatively common in the forests along other Slovenian rivers (13) and it looks like it will spread along the Mura River too.

According to Hejda \& Pyšek (44), conservation or management decisions based on impact need to realize that the effect of individual IAS largely differs. The effect on community characteristics is determined by the character of the invaded community. Therefore, it is more appropriate to measure the impact of invasion by examining the traits of species forming the post-invasion community, rather than simply checking the number of species lost due to invasion.

Sustainable and close-to-nature forest management (small-scale cutting, rejuvenation in small gaps etc.), including conservation management of studied riparian and flooded forests, should give priority to enable the rejuvenation of key tree species which is now disabled due to presence of IAS. According to the fact that IAS are mainly light demanding species some sylvicultural measures should be considered. Restricting the influx of light with keeping tree crown densities thick, mostly with low logging intensity (especially in the FHT 91F0), site preparation for planting and artificial rejuvenation with adequate regional tree reproductive material, planted mainly with tall, few years old seedlings, are just some of the measures. Our study showed that the type and intensity of forestry measurement utilized in floodplain forests play an important role in intrusion of IAS. Privately owned forests, irrespective of the FHT, which turned out as the forests with less dense canopy cover and consequently with higher light intensity are in our case more prone to the intrusion of IAS.

Lastly, rising awareness and informing of stakeholders in forests (owners, foresters, hunters, beekeepers etc.) should be considered because many of them do not understand all the threats (and benefits?) of IAS. We also think that efficient monitoring system of IAS must be established at the national level.

\section{Acknowledgement}

This survey was done in the framework of the project GoForMura, funded by the EEA Financial Mechanism 2009-2014 (SI02), Government Office for Development and European Cohesion Policy of the Republic of Slovenia and Slovenian Research Agency (P4-0107). The authors would like to thank Andreja Ferreira for the assistance with the graphic image and to Urša Marinšek who kindly reviewed our English.

\section{REFERENCES}

1. KNEZEVIC SZ 2017 Invasive plant species. In: THOMAS B, MURRAY BG, MURPHY DJ (eds.). Encyclopedia of Applied Plant Sciences, Vol. 1. Plant physiology and development. Elsevier Ltd.: 300-302.

https://doi.org/10.1016/B978-0-12-394807-6.00021-6

2. ANONYMOUS 2014a Life and invasive alien species. European Commission, $\mathrm{p} 77$

3. ESSL F, RABITSCH W 2002 Neobiota in Österreich. Umweltbundesamt. (German), Wien. EU. 2014. Regulation (EU) No 1143/2014 of the European Parliament and of the council of October 2014 on the prevention and management of the introduction and spread of invasive alien species. Official Journal of the European Union L 317/35. Brussels.

4. CLOSSET-KOPP D, CHABRERIE O, VALENTIN B, DELACHAPELLE H, DECOCQ G 2007 When Oskar meets Alice: Does a lack of trade-off in r/K-strategies make Prunus serotina a successful invader of European forests? Forest Ecol Manag 247 (1-3): 120-130. https://doi.org/10.1016/j.foreco.2007.04.023

5. PAIRON M, PETITPIERRE B, CAMPBELL M, GUISAN A, BROENNIMANN O, BARET PV, JACQUEMART AL, BESNARD G 2010 Multiple introductions boosted genetic diversity in the invasive range of black cherry (Prunus serotina; Rosaceae). Ann Bot 105: 881-890. https://doi.org/10.1093/aob/mcq065 
6. HALAREWICZ A, ŽOŁNIERZ Z 2014 Changes in the understorey of mixed coniferous forest plant communities dominated by the American black cherry (Prunus serotina Ehrh.) Forest Ecol Manag 313: 91-97. https://doi.org/10.1016/j.foreco.2013.11.006

7. STRAYER DL, EVINER VT, JESCHKE JM, PACE ML 2006 Understanding the long-term effects of species invasions. Trends Ecol Evol 21(11): 645-651. https://doi.org/10.1016/j.tree.2006.07.007

8. ANONYMOUS 2014b Invasive alien species. European Commission, $\mathrm{p} 28$

9. PRAX A, RICHTER W, ČERMÁK J, HYBLER V 2008 The hydrological and moisture regime of soils and floodplain forests. In: KLIMO E (ed). Floodplain forests of the temperate zone of Europe. Lesnická práce, s.r.o.: 75-102

10. KLIMO E, HAGER H 2008 Preface. In: KLIMO E (ed.). Floodplain forests of the temperate zone of Europe. Lesnická práce, s.r.o.: 6-11

11. ŠKORNIK S, ŠAJNA N, KRAMBERGER B, KALIGARIČ S, KALIGARIČ M 2008 Last remnants of riparian wooded meadows along the middle Drava River (Slovenia): species composition is a response to light conditions and management. Folia Geobot: a journal of plant ecology and systematics 43 (4): 431-445

12. SCHNITZLER A, HALE BW, ALSUM E 2007 Examining native and exotic species diversity in European riparian forests. Biol Conserv 138: 146-156. https://doi.org/10.1016/j.biocon.2007.04.010

13. ZELNIK I 2012 The presence of invasive alien plant species in different habitats: case study from Slovenia. Acta Biol Slo 55: 25-38

14. KOŠIR P, ČARNI A, MARINŠEK A, ŠILC U 2013 Floodplain forest communities along the Mura River (NE Slovenia). Acta Bot Croat 72 (1): 71-95. https://doi.org/10.2478/v10184-012-0015-7

15. MARINŠEK A, ČARNI A, KUTNAR L, PLANINŠEK Š 2016 Vrstno bogati in naravovarstveno pomembni, a močno ogroženi poplavni gozdovi ob Muri (Species-rich and important for conservation but threatened forests along Mura River, in slovenian). Proteus 78: $274-280$

16. CATER M, KUTNAR L 2008 Prekmurje-watershed of the rivers Mura, Ledava, and Ščavnica. In: Klimo, E. (ed.). Floodplain forests of the temperate zone of Europe. 1st ed. Lesnická práce, Kostelec nad Černými lesy: 584-592

17. ČARNI A, KOŠIR P, MARINČEK L, MARINŠEK A., ŠILC U, ZELNIK I 2008 Komentar k vegetacijski karti gozdnih združb Slovenije v merilu 1:50.000 - list Murska Sobota (Commentary to the vegetation map of forest communities of Slovenia in scale of 1:50.000 - Section Murska Sobota, in slovenian). Pomurska akademska znanstvena unija - PAZU. p 64

18. DAKSKOBLER I, KUTNAR L, ŠILC U 2013 Floodplain woods, swamp woods and riverine forests in Slovenia. Silva Slovenica Slovenian Forestry Institute, Ljubljana, p 127

19. GORŠAK B, BAKAN B 2003 Krajinski park Mura (Landscape park Mura, in slovenian). Proteus 65: 311-322

20. ELLENBERG H, WEBER HE, DUILL R, WIRTH V, WERNER W, PAULISSEN D. 1992 Zeigerwerte von Pflanzen in Mitteleuropa, 2. ed. Scr Geobot, 18: 1-258

21. BAKAN B 2006 Slikovni pregled višjih rastlin Prekmurja: prispevek k poznavanju flore Prekmurja. Razvojni center, Lendava, $p$ 145

22. IVAJNŠIČ D, COUSINS SAO, KALIGARIČ M 2012 Colonization by Robinia pseudoacacia of various soil and habitat types outside woodlands in a traditional Central-European agricultural landscape. Pol J Ecol 60 (2): 301-309

23. RUDOLF S, BRUS R 2006 Razširjenost in invazivnost robinije (Robinia pseudoacacia L.) v severovzhodni Sloveniji (Distribution and invasiveness of black locust (Robinia pseudoacacia L.) in northeast Slovenia, in slovenian). Gozdarski vestnik 64: 134-159
24. GLOBEVNIK L, MIKOŠ M 2009 Boundary conditions of morphodynamic processes in the Mura River in Slovenia. Catena 79: 264-276. https://doi.org/10.1016/j.catena.2009.06.008

25. EC - European Commission 1992 Council Directive 92/43/EEC of 21 May 1992 on the conservation of natural habitats and of wild fauna and flora. http://eur-lex.europa.eu/legal-content/EN/ TXT/?uri=CELEX:31992L0043

26. EC - European Commission 2007 Interpretation Manual of European Union Habitats - EUR27. European Commission, DG Environment http://ec.europa.eu/environment/nature/legislation/ habitatsdirective/docs/2007_07_im.pdf

27. BRAUN-BLANQUET J 1964 Pflanzensoziologie. Grundzüge der Vegetationskunde. Springer, Wien. https://doi.org/10.1007/978-3-7091-8110-2

28. DELL INC 2016 Dell Statistica (data analysis software system), version 13. software.dell.com.

29. MARTINČIČ A, WRABER T, JOGAN N, PODOBNIK A, TURK B, VREŠ B 2007 Mala flora Slovenije - Ključ za določanje praprotnic in semenk (Flora of Slovenia - Identification Key for Ferns and Vascular Plants, in slovenian). Tehniška založba Slovenije, Ljubljana, p 968

30. JOGAN N, BAČIČ M, STRGULC KRAJŠEK S 2012 Tujerodne in invazivne vrste v Sloveniji (Alien and invasive plants in Slovenia (in slovenian). In: JOGAN N, BAČIČ M, STRGULC KRAJŠEK $S$ (ed.) 2012 Neobiota Slovenije, final project report. Department of Biology, Biotechnical Faculty, University of Ljubljana, Ljubljana, p 272

31. ZELNIK I, MAJA HALER M, GABERŠČIK A 2015 Vulnerability of a riparian zone towards invasion by alien plants depends on its structure. Biologia 70 (7): 869-878. https://doi.org/10.1515/biolog-2015-0110

32. HEJDA M, PYŠEK P, JAROŠÍK V 2009 Impact of invasive plants on the species richness, diversity and composition of invaded communities. J Ecol 97: 393-403. https://doi.org/10.1111/j.1365-2745.2009.01480.x

33. TIÉBRÉ MS, SAAD L, MAHY G 2008 Landscape dynamics and habitat selection by the alien invasive Fallopia (Polygonaceae) in Belgium. Biodivers Conserv 17: 2357-2370. https://doi.org/10.1007/s10531-008-9386-4

34. HEJDA M 2012 What is the impact of Impatiens parviflora on diversity and composition of herbal layer communities of temperate forests? PLoS ONE 7(6): e39571. doi: 10.1371/journal. pone.0039571. https://doi.org/10.1371/journal.pone.0039571

35. POWELL KI, CHASE JM, KNIGHT TM 2011 A synthesis of plant invasion effects on biodiversity across spatial scales. Am J Bot 98: 539-548. https://doi.org/10.3732/ajb.1000402

36. VILÁ M, ESPINAR JL, HEJDA M, HULME PE, JAROŠÍK V, MARON JL, PERGL J, SCHAFFNER U, SUN Y, PYŠEK P 2011 Ecological impacts of invasive alien plants: a meta-analysis of their effects on species, communities and ecosystems. Ecol Lett 14: 702-708. https://doi.org/10.1111/j.1461-0248.2011.01628.x

37. LIAO C, PENG R, LUO Y, ZHOU X, WU X, FANG C, CHEN J, LI B 2008 Altered ecosystem carbon and nitrogen cycles by plant invasion: a meta-analysis. New Phytol 177: 706-714. https://doi.org/10.1111/j.1469-8137.2007.02290.x

38. EHRENFELD JG 2010 Ecosystem consequences of biological invasions. Annu Rev Ecol Evol Syst 41: 59-80. https://doi.org/10.1146/annurev-ecolsys-102209-144650

39. PEJCHAR L, MOONEY HA 2009 Invasive species, ecosystem services and human well-being. Trends Ecol Evol 24: 497-504. https://doi.org/10.1016/j.tree.2009.03.016

40. PYŠEK P, RICHARDSON DM, PERGL J, JAROŠÍK V, SIXTOVÁ Z, WEBER E 2008 Geographical and taxonomic biases in invasion ecology. Trends Ecol Evol 23: 237-244. https://doi.org/10.1016/j.tree.2008.02.002

41. RICHARDSON DM, MACDONALD IA, FORSYTH GC 1989 Reduction in plant species richness under stands of alien trees and shrubs in fynbos biome. S Afr for J 149: 1-8 
42. PYŠEK P, PYŠEK A 1995 Invasion by Heracleum mantegazzianum in different habitats in the Czech Republic. J Veg Sci 6: 711-718. https://doi.org/10.2307/3236442

43. BÍMOVÁ K, MANDÁK B, KAŠPAROVÁ I 2004 How does Reynoutria invasion fit the various theories of invasibility? J Veg Sci 15: 495-504. https://doi.org/10.1658/1100-9233(2004)015[0495:HDRIFT]2.0.CO;2

44. HEJDA M, PYŠEK P 2006 What is the impact of Impatiens glandulifera on species diversity of invaded riparian vegetation? Biol Conserv 132: 143-152.

https://doi.org/10.1016/j.biocon.2006.03.025

45. PYŠEK P, PRACH k 1993 Plant invasions and the role of riparian habitats: a comparison of four species alien to central Europe. J Biogeogr 20: 413-420

46. MÜLLEROVÁ J, PYŠEK P, JAROŠÍK V, PERGL J 2005 Aerial photographs as a tool for assessing the regional dynamics of the invasive plant species Heracleum mantegazzianum. J Appl Ecol 42: 1042-1053. https://doi.org/10.1111/j.1365-2664.2005.01092.x

47. BEERLING DJ, PERRINS JM 1993 Impatiens glandulifera Royle (Impatiens Roylei Walp). J Ecol 81: 367-382. https://doi.org/10.2307/2261507

48. RUCKLI R, RUSTERHOLZ HP, BAUR B 2014 Invasion of an annual exotic plant into deciduous forests suppresses arbuscular mycorrhiza symbiosis and reduces performance of sycamore maple saplings. For Ecol Manag 318: 285-293

49. D'ANTONIO CM, LEVINE JM, THOMSON M 2001 Ecosystem resistance to invasion and the role of propagule supply: a California perspective. Ecol Mediterr 27: 233-245

50. DAEHLER CC 2003 Performance comparisons of co-occurring native and alien invasive plants: implications for conservation and restoration. Annu Rev Ecol Evol Syst (34): 183-211. https://doi.org/10.1146/annurev.ecolsys.34.011802.132403

51. OGDEN JAE, REJMÁNEK M 2005 Recovery of native plant communities after the control of a dominant invasive plant species, Foeniculum vulgare: implications for management. Biol Conserv 125: 427-439. https://doi.org/10.1016/j.biocon.2005.03.025

52. HULME PE, BREMNER ET 2005 Assessing the impact of Impatiens glandulifera on riparian habitats: partitioning diversity components following species removal. J Appl Ecol 43: 43-50

53. WADSWORTH RA, COLLINGHAM YC, WILLIS SG, HUNTLEY B, HULME PE 2000 Simulating the spread and management of alien riparian weeds: are they out of control? J Appl Ecol 37 (Suppl. 1): 28-38.

https://doi.org/10.1046/j.1365-2664.2000.00551.x

54. PRACH K 1994 Seasonal dynamics of Impatiens glandulifera in two riparian habitats in central England. In: DE WAAL LC (Ed.), Ecology and Management of Invasive Riverside Plants. John Wiley Sons, Chichester: 127-133 